\title{
Socio-Demographic and Economic Correlates of Climate Change Coping and Adaptation Strategies: A Study on the Farmer Communities in Barisal District, Bangladesh
}

\author{
Md. Nazmul Huda1, Muhammad Zakir Hossin'², Syed Ashik-E-Elahi' ${ }^{3}$, Farzana Mahbub ${ }^{4}$ \\ ${ }^{1}$ School of Public Health and Community Medicine, University of New South Wales, Sydney, Australia \\ ${ }^{2}$ Centre for Health Equity Studies, Stockholm University/Karolinska Institute, Stockholm, Sweden \\ ${ }^{3}$ Department of Development and Governance Studies, Northern University, Dhaka, Bangladesh \\ ${ }^{4}$ Faculty of Business Administration, Eastern University, Dhaka, Bangladesh \\ Email: nazmulsoc2008@gmail.com
}

Received 23 December 2015; accepted 4 June 2016; published 9 June 2016

Copyright (C) 2016 by authors and Scientific Research Publishing Inc.

This work is licensed under the Creative Commons Attribution International License (CC BY).

http://creativecommons.org/licenses/by/4.0/

c) (i) Open Access

\begin{abstract}
The major objective of the study is to apply Conservation of Resource (COR) theory for examining the influence of farmers' socio-demographic and economic correlates upon their adoption of agricultural, economic and emotion-focused coping and adaptation strategies of climate change. An interview schedule developed from the COR theory was utilized for data collection. Using multistage cluster sampling technique, a total of $\mathbf{3 8 4}$ farmers were chosen from Agailjhara Upazila of Barisal District and interviewed through a predesigned structured questionnaire. For triangulation of the quantitative findings, the study employed case study technique to collect qualitative data from the respondents. The findings of the study demonstrate that the most common emotionfocused, agricultural and economic coping and adaptation strategies of climate change were social support seeking $(79.69 \%)$, planting trees $(71.35 \%)$, homestead gardening $(52.08 \%)$, hydroponic farming/floating garden $(46.88 \%)$, duck rearing $(30.73 \%)$, saving $(20.83 \%)$, self-insurance $(18.75 \%)$, etc. Bivariate results indicate that age, ownership of land, income and ownership of television or mobile phone were found significantly correlated with the three variables, including economic, agricultural and emotion-focused coping and adaptation strategies of COR theory. Again, access to microcredit has relationship with economic and agricultural adaptation strategies. Furthermore, education has significant relationship with agricultural adaptation strategies. The study suggests that continuous researches by policy makers, researchers, GOs and NGOs are very essential to exploring and enhancing farmers' coping and adaptation strategies which may relegate the adverse impacts and vulnerabilities of climate change in the study area.
\end{abstract}




\section{Keywords}

\section{COR Theory, Climate Change, Coping and Adaptation Strategies, Farmers, Socio-Demographic and Economic Correlates}

\section{Introduction}

Climate change, the change in the mean state of the climate or in its variability, persisting for an extended period, is considered as a threat multiplier which aggravates environmental, social, and economic challenges in Bangladesh [1]-[3]. Studies show that Bangladesh is the most climate vulnerable country in the whole world due to its geography, topography, and high population density [4] [5]. Also, it has limited human, institutional and financial capacity to anticipate and respond to the direct and indirect effects of climate change [6]-[9]. As consequences, climatic hazards such as continuous flooding, cyclone and tidal surge have affected the agriculture sector, which is particularly important in economic terms, of farmer communities in the coastal zones of Bangladesh [10] [11].

Again, in a disaster prone country like Bangladesh where there is widespread poverty and dependence on the natural environment, climate change may intensify existing problems and create new combinations of risks. Accordingly, there is a growing need for proactive adaptation and coping strategies to mitigate climate change risks and vulnerabilities [2] [12]. Adaptation is a broad concept which covers proactive actions by individuals, communities, NGOs and GOs. It can be defined as "adjustment in natural or human systems in response to actual or expected climatic stimuli or their effects, which moderates harm or exploits beneficial opportunities while coping strategies mean individual or community responses to change in environmental conditions, or responses to its consequences" [13]. In other words, a coping strategy is a short-term response in securing livelihood system to periodic stress [14].

Existing literature lacks useful information regarding climate change coping and adaptation strategies in Bangladesh. Only a few noteworthy researches have been carried out so far to study the climate change coping and adaptation strategies. Anik and Khan [15] identified 16 adaptive measures in the north eastern region of Bangladesh within which crop diversification, floating garden, duck rearing, cage aquaculture, wave protection walls, re-digging of canal and construction of embankments were popular. Selvaraju et al. [16] examined some coping and adaptation strategies in Bangladesh, including pond excavation, integrated crop-livestock farming systems, drought-tolerant crop varieties, cropping systems and homestead gardening. Ministry of Environment and Forest, Bangladesh [8] in a study explored some coping and adaptation strategies which people undertook during the period of natural disasters, including cyclone, drought, high flood, tidal surge and flash flood. These coping and adaptation strategies comprise increasing investment on cyclone shelter, adoption of "water saving technology" and/or "water reuse technology", deep (hand) tube wells, safe relocation during high flood, early warning system, community preparedness and awareness, etc. Still there is a paucity of scientific literature in this area.

In Bangladesh, no study has been carried out yet to explore the economic, agricultural and emotion-focused coping and adaptation strategies of climate change. Therefore, in this study, an examination of the COR theory has been used to identify economic, agricultural and emotion-focused coping and adaptation strategies among the farmers of Barisal District in Bangladesh, which vary by their socio-demographic and economic factors. A few studies have been conducted in the developing countries including Bangladesh to show the influence of respondents' socio-demographic and economic factors on undertaking climate change coping and adaptation strategies. For example, Enujeke and Ofuoku [17] explored farmers' socio-demographic factors affecting climate change adaptation strategies in Nigeria. The results of their study revealed that level of education, household size, visit to other farmers (farmer-to-farmer extension) and attendance to farmers' meetings had significantly and positively impacted on adaptation to climate change. Again, Deressa et al. [18] studied the association between respondents' years of schooling and climate change adaptation strategies. The findings of their study displayed that a unit increase in number of years of schooling would result in a $1 \%$ increase in the probability of soil conservation and a $0.6 \%$ increase in change in planting dates to adapt to climate change. 
Recently, Anyoha et al. [19] determined the socio-economic factors influencing climate change adaptation strategies among crop farmers in Umuahia south area of Abia state, Nigeria. The results of their study showed that sex, farm size, farming experience, household size, and access to social organization were significantly related to climate change adaptation strategies. In the same country, Nwaiwu et al. [20] found the robust relationship between age and income with the climate change adaptation strategies. Furthermore, Franzel [21] in his investigation in Africa discovered a positive correlation between income and adoption of agricultural adaptation strategies. However, Shiferaw and Holden [22] indicated a negative relationship between age and adoption of improved soil conservation practices. In Bangladesh, Anik and Khan [15] identified the robust positive association between income and economic adaptation strategies. Thus, the socio-demographic and economic characteristics of the respondents have significant influence upon their undertaking of climate change coping and adaptation strategies. Therefore, the following research hypothesis guides this study: There is an influence of farmers' socio-demographic and economic correlates upon their adoption of agricultural, economic and emotion-focused coping and adaptation strategies of climate change.

\section{Theoretical Framework: COR Theory}

COR theory is a motivational stress theory according to which individuals strive to obtain, retain, and protect what they value. The basic tenet of COR theory is that people have an innate as well as a learned desire to conserve the quality and quantity of their resources and to limit any state that may jeopardize the security of these resources [23] [24]. These resources can be objects (e.g., crops, forestry); personal characteristics (e.g., occupational skills, sense of self-esteem); or energies (e.g., money, credit, insurance). Resources are important not merely for their face value but because they define who we are. It is the actual or potential loss of these resources that threaten our identity or livelihood [25]. Damage and loss of resources may result in mental or physical stress-outcomes. In the short term, these may be negative emotions, such as anger, frustration or fear. These may also be more severe mental and physical consequences, such as burnout, depression, which generally occur over the long term [23] [24] [26] [27].

While addressing the impacts of climate change induced natural disasters by this theory, three types of coping and adaptation strategies are identified (as shown in Figure 1). First one is agricultural adaptation strategies, most commonly early sowing of seeds, hydroponic farming, herds' diversification, plant protection, purchasing of forage, investment in shallow or deep tube wells, and cultivating more water-efficient crops. Second type of adaptation strategies are economic adaptation strategies which include saving, self-insurance etc. [24] [27].

Following COR theory, coping strategies other than agricultural and economic also need to be incorporated in the sequence and their effects in terms of preserving non-material resources need to be assessed. Social support

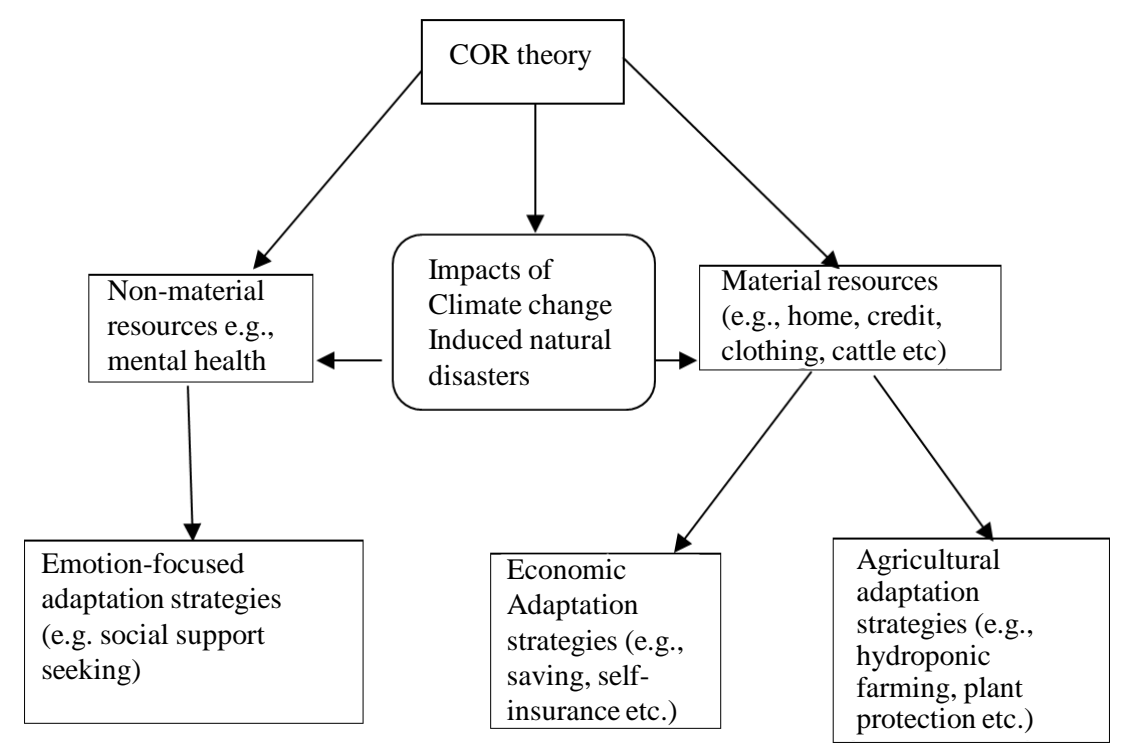

Figure 1. A schematic outline of COR theory. 
seeking is one of the emotion-focused coping strategies. Empirical studies have shown that many people rely on their social networks to moderate the effects of climate change [28] [29]. These are typically informal support networks consisting of family, neighbors and friends. Thus, emotion-focused coping strategies may play an important role in conserving personal resources, such as a sense of coherence and meaning in life, which are important prerequisites for mental health [23] [24] [26].

\section{Materials and Methods}

\subsection{Overview of the Study Area}

The study area, Agailjhara Upazila (subdistrict), which is under Barisal District, is situated in southern-central Bangladesh. Approximately 39\% of the inhabitants in the study area depend on agriculture for their livelihood [30]. The climate is characterized by hot and humid summer, cold winter as well as a moderately high temperature for about 8 months in a year. The maximum temperature is $35.1^{\circ} \mathrm{C}$ in summer and minimum $12.1^{\circ} \mathrm{C}$ in winter season while annual rainfall is about $1955 \mathrm{~mm}$ [31].

\subsection{Design and Participants}

In this study, multi-stage random sampling design was used to identify the respondents. At the outset, the researchers randomly chose Agailjhara Upazila out of the ten upazilas in Barisal district. At the second stage, a list of 95 villages was collected from Agailjhara Upazila Parishad office, out of which four villages were picked up based on a lottery method. Four trained field investigators were employed in four sampled villages in order to gather relevant data from the farmers. At the final stage, 96 farmers from each of the four selected villages were randomly chosen from the lists collected from the Union Parishad office. Therefore, each respondent had the same probability of being selected in the present study. Thus, a total of 384 respondents constituted the sample size for the study. However, in case of unavailability of any selected respondent, the investigators interviewed an alternative respondent from the list, resulting in a non-response rate of zero.

\subsection{Study Instruments}

Drawing on the COR theory, a structured questionnaire was designed to explore the influence of farmers' sociodemographic and economic factors upon their adoption of economic, agricultural, as well as emotion-focused climate change coping and adaptation strategies (as shown in Figure 2). The survey questionnaire, containing information regarding socio-demographic and economic characteristics of farmers and their economic, agricultural, as well as emotion-focused coping and adaptation strategies of climate change, was administered to collect data from the farmers in the study areas. Before going to the study sites, the questionnaire was translated into Bangla. Moreover, a separate checklist, containing information on the same, was developed to collect qualitative data that allowed us to cross-validate the survey findings. Respondents were approached directly. Informed consent was obtained before approaching them.

\subsection{Data Analysis}

Data from the questionnaire were analyzed using the Statistical Package for the Social Sciences (SPSS) software (version 16). The data on the socio-demographic and economic characteristics of farmers and variables of COR

\begin{tabular}{|c|c|c|}
\hline \multirow{3}{*}{$\begin{array}{l}\text { Socio-demographic and } \\
\text { economic } \\
\text { characteristics } \\
\text { Age } \\
\text { Education } \\
\text { Ownership of land } \\
\text { Access to microcredit } \\
\text { Income } \\
\text { Ownership of television } \\
\text { or mobile phone }\end{array}$} & \multirow{3}{*}{ 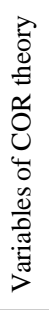 } & $\begin{array}{l}\text { Economic adaptation strategies e.g., } \\
\text { saving self-insurance, duck rearing, } \\
\text { investment on cyclone shelter }\end{array}$ \\
\hline & & $\begin{array}{l}\text { Agricultural adaptation strategies such } \\
\text { hydroponic farming, plant protection, } \\
\text { homestead gardening etc. }\end{array}$ \\
\hline & & $\begin{array}{l}\text { Emotion-focused coping strategies such } \\
\text { as social support seeking, and awareness }\end{array}$ \\
\hline
\end{tabular}

Figure 2. Conceptual framework of the study (self-designed). 
theory were presented in frequency and percentage form of categorized responses. In the process of analysis, relationships supporting or refuting the pre-formulated hypothesis were subjected to statistical tests of significance. The test statistic of Phi was used to measure the magnitude/strength of relationships among the study variables.

\section{Results and Discussion}

\subsection{Socio-Demographic Characteristics of Farmers}

Table 1 shows that the mean age of the study sample was 48.67 years with a standard deviation of 14.28 and a range of 15 to 71 years. The highest proportion (60.94\%) of the respondents was under the age of 40 years. The sample was dominated by the male participants $(92.71 \%)$. Again, the majority of the farmers were predominantly married (74\%) and Muslims (80.73\%). Education is an influential factor affecting farmers' climate change coping and adaptation strategies. In the sample, approximately half of the farmers have no formal education. These sample characteristics of the current study are largely consistent with those of the study conducted by Uddin [32] on dynamics of cyclone evacuation behavior among the coastal residents in Bangladesh. In contrast to this, 28\% of the respondents had no formal education in a study carried out by Enujeke and Ofuoku [17] on the farmers in Edo state, Nigeria.

Table 1. Socio-demographic and economic correlates of farmers $(n=384)$.

\begin{tabular}{|c|c|c|}
\hline Socio-demographic and economic correlates & Number & Percent \\
\hline \multicolumn{3}{|l|}{ Age (in yrs) } \\
\hline $\begin{array}{l}<40 \\
\geq 40\end{array}$ & $\begin{array}{l}150 \\
234\end{array}$ & $\begin{array}{l}39.06 \\
60.94\end{array}$ \\
\hline \multicolumn{3}{|l|}{ Gender } \\
\hline Male & 356 & 92.71 \\
\hline Female & 28 & 7.29 \\
\hline \multicolumn{3}{|l|}{ Religion } \\
\hline Muslim & 310 & 80.73 \\
\hline Hindu & 74 & 19.27 \\
\hline \multicolumn{3}{|l|}{ Educational status } \\
\hline No formal education & 186 & 48.44 \\
\hline Formal education & 198 & 51.56 \\
\hline \multicolumn{3}{|l|}{ Amount of land ownership (in acres) } \\
\hline$<3$ & 305 & 79.43 \\
\hline$>3$ & 79 & 20.57 \\
\hline \multicolumn{3}{|l|}{ Access to microcredit loan } \\
\hline Yes & 123 & 32.03 \\
\hline No & 261 & 67.97 \\
\hline \multicolumn{3}{|l|}{ Monthly income (in Taka) } \\
\hline$\leq 8000$ & 170 & 44.27 \\
\hline$>8000$ & 214 & 55.73 \\
\hline \multicolumn{3}{|l|}{ Ownership of television or mobile phone } \\
\hline Yes & 219 & 57.03 \\
\hline \multirow[t]{2}{*}{ No } & 165 & 42.97 \\
\hline & Mean & Std. Dev. \\
\hline Age & 48.67 & 14.28 \\
\hline Income & 10,711 & 1528 \\
\hline
\end{tabular}

Source: Field survey, 2012. 
Of 384 farmers who participated in the present study, 79.43\% have less than 3 acres of land while $32.03 \%$ of them have access to microcredit loans from ASA and BRAC NGOs. The income distribution of the farmers shows that more than half of the respondents (55.73\%) earn more than TK 8,000 monthly. Media like television or mobile phone seem to have played a role in exposing the issues of climate change adaptation strategies [33]. These media are essential to increasing climate change coping and adaptation strategies. The results of the current study demonstrate that about $57 \%$ of the farmers own television or mobile phone while a substantial number of respondents (43\%) do not have those.

\subsection{Farmers' Coping and Adaptation Strategies of Climate Change}

Of the 384 farmers, around 31 percent reported undertaking duck rearing as a way of income generation for mitigating the risk of climate change, followed by saving (20.83\%), self-insurance (18.75\%) and investment on cyclone center (10.42\%). Again, respondents were asked what kinds of agricultural adaptation strategies they undertook for coping with climate change. As seen in Table 2, the most common agricultural adaptation strategy stated by the study participants was planting trees (71.35\%). The second important agricultural adaptation strategy was the homestead gardening (52.08\%) followed by hydroponic farming/floating garden (46.88\%). With regard to the emotion-focused coping strategy, the study found that a whopping $79.69 \%$ of the respondents reported having sought social support during the period of natural disasters.

These findings of the study are in line with a good number of studies [8] [15] [19] [32] [34]-[39]. On the contrary, Hossain and Roy [40] carried out a study on the community based risk assessment and adaptation to climate change in the coastal wetlands of Bangladesh. Their study findings reveal that people hardly adopt any local adaptation strategies which are based on indigenous knowledge. Rather, they depend on expensive diesel driven ground water irrigation, varieties of foreign seed and fertilizer.

The following quotation from another participant of a case study matches the quantitative findings.

"I sought social support from my neighbors and friends during the time of natural disasters since it cost no money and enhanced mental strengths, thereafter we found a meaningful social life. Besides, I adopted some agricultural adaptation strategies such as floating garden (locally called dhap), homestead gardening, and plant protection which helped me a lot to avert poverty resulted from the ravaging impacts of climate change” (46-year-old Sonaban Begum).

Again, the following quotation from a respondent of a case study depicts the importance of adaptation strategies.

"The 1998 flood plunged my once acre has of land into river and completely devastated two rice mills which were at the bank of Paisarhat River. Cyclone Sidr and Aila were the other two devastating blows to my life. I picked some loans from BRAC, which helped me to purchase forage for cows, build plinth height of my house, plant trees and adopt hydroponic farming" (57-year-old Enamul).

Table 2. Distribution of farmers by economic, agricultural and emotion-focused coping and adaptation strategies.*

\begin{tabular}{llc}
\hline Climate change coping and adaptation strategies & Number & Percent \\
\hline Economic adaptation strategies & & 20.83 \\
Saving & 70 & 18.75 \\
Self-insurance & 72 & 30.73 \\
Duck rearing & 118 & 10.42 \\
Investment on cyclone shelter & 40 & 46.88 \\
Agricultural adaptation strategies & 180 & 71.35 \\
Hydroponic farming/floating garden & 274 & 52.08 \\
Planting trees & 200 & 79.69 \\
Homestead gardening & 306 & 2 \\
Emotion-focused coping strategy (e.g., social support seeking) & & 2 \\
\hline
\end{tabular}

Source: Field survey, 2012; *Multiple responses were permitted. 


\subsection{Relationship between Socio-Demographic and Economic Correlates and the Variables of COR Theory}

\subsubsection{Relationship between Socio-Demographic and Economic Correlates and Economic Adapta- tion Strategies}

The findings of the study suggest that economic adaptation strategies are significantly related to five socio-demographic factors such as age, ownership of land, access to microcredit, income and ownership of television or mobile phone(as shown in Table 3). In terms of age, the results indicate that farmers with older age are more likely to adopt economic adaptation strategies such as saving, self-insurance, investment on cyclone center and so on. Because the older farmers experienced devastating impacts of climate change in the past, they tend to undertake economic adaptation strategies in advance. Again, ownership of land and access to microcredit has relationship with economic adaptation strategies. It implies that respondents having less amount of land and those with no access to microcredit are less likely to adopt economic adaptation strategies. The crucial reason behind this type of relationship might be that farmers who have less amount of land and no access to microcredit are economically too insolvent to undertake economic adaptation strategies such as savings or self-insurance and investment on cyclone center. These results of the current study are consistent with those of the study investigated by Anyoha et al. [19] on socio-economic factors influencing climate change adaptation strategies among the crop farmers in Nigeria.

Income is positively related to this dependent variable. The results of the study show that farmers of higher income group are more likely to undertake economic adaptation strategies. This finding of the current study is supported by the findings of the studies conducted by Anik and Khan [15] and Nwaiwu et al. [20], which implies that the higher the income of the respondents, the greater the tendency to adopt economic adaptation strategies. On the other hand, the study finding is not compatible with that of the study carried out by Enujeke and Ofuoku [17]. Their study results demonstrate that farmers' income did not have a positive relationship with adaptation to climate change. Ownership of television or mobile phone is another important factor which has also strong relationship with economic adaptation strategies. It indicates that respondents who own television or mobile phone show greater propensity to report that they adopt economic coping strategies since they get aware of the importance of economic adaptation strategies during the time of climatic hazards such as flood, cyclone and tidal surge through television or mobile phone.

\subsubsection{Relationship between Socio-Demographic and Economic Correlates and Agricultural Adaptation Strategies}

Table 3 shows the relationship between some selected socio-demographic and economic correlates and agricultural adaptation strategies. The phi value demonstrates that age is positively and significantly related to agricultural adaptation strategies such as hydroponic farming, plant protection, homestead gardening, duck rearing and so on. This suggests that respondents with older age are more likely to adopt agricultural adaptation strategies in the study area. This is contrary to the findings of the study done by Enujeke and Ofuoku [17] in Nigeria. According to their study, the age of the farmers did not have a significant relationship with agricultural adaptation to climate change. Again, Shiferaw and Holden [22] found a negative relationship between age and adoption of

Table 3. Summary table of Phi values on variables of COR theory by socio-demographic and economic correlates.

\begin{tabular}{|c|c|c|c|}
\hline \multirow[b]{2}{*}{$\begin{array}{l}\text { Socio-demographic and } \\
\text { economic correlates }\end{array}$} & \multicolumn{3}{|c|}{ Variables of COR theory } \\
\hline & $\begin{array}{l}\text { Whether they adopt economic } \\
\text { adaptation strategies }\end{array}$ & $\begin{array}{l}\text { Whether they choose } \\
\text { agricultural adaptation strategies }\end{array}$ & $\begin{array}{l}\text { Whether they undertake } \\
\text { emotion-focused coping strategies }\end{array}$ \\
\hline Age & $\mathrm{Phi}=0.40^{* *}$ & Phi $=0.35^{* *}$ & Phi $=0.68^{* *}$ \\
\hline Education & Phi $=0.06$ & $\mathrm{Phi}=0.30^{*}$ & Phi $=0.68$ \\
\hline Ownership of land & $\mathrm{Phi}=0.56^{* *}$ & $\mathrm{Phi}=0.59 *$ & $\mathrm{Phi}=0.31^{* *}$ \\
\hline Access to microcredit & $\mathrm{Phi}=0.35^{*}$ & $\mathrm{Phi}=0.18^{*}$ & Phi $=0.42$ \\
\hline Income & $\mathrm{Phi}=0.27^{*}$ & $\mathrm{Phi}=0.67 * *$ & $\mathrm{Phi}=0.49 * *$ \\
\hline $\begin{array}{c}\text { Ownership of television or } \\
\text { mobile phone }\end{array}$ & $\mathrm{Phi}=0.25^{*}$ & $\mathrm{Phi}=0.27^{*}$ & $\mathrm{Phi}=0.37^{* *}$ \\
\hline
\end{tabular}

Source: Field survey, 2012; ${ }^{* *} \mathrm{p}<0.01 ;{ }^{*} \mathrm{p}<0.05$. 
improved soil conservation practices in Ethiopia.

Education is another key determinant of agricultural adaptation strategies. The findings of the current study display that farmers with formal education are more likely to adopt agricultural adaptation strategies. This is congruent with the findings of the studies conducted by Enujeke and Ofuoku [17] and Anyoha et al. [19] in Nigeria. With regard to ownership of land and access to microcredit, results of the study reveal that farmers having less amount of land and those who have access to microcredit are more likely to undertake agricultural adaptation strategies. In terms of income, this study finds that income has a positive correlation with the dependent variable. It exhibits that participants who have more income are more likely to report that they undertake agricultural adaptation strategies. This is in consonance with the findings of the researches conducted by Daulagala et al. [41] and Franzel [21], which discovered a positive correlation between income and adoption of agricultural adaptation strategies. Similarly, respondents who have television or mobile phone are more likely to adopt agricultural adaptation strategies since they have been aware of climate change coping and adaptation strategies through the access to and availability of television or mobile phone.

\subsubsection{Relationship between Age, Ownership of Land, Income and Ownership of Television or Mo- bile Phone and Emotion-Focused Coping Strategies}

The third variable of COR theory is emotion-focused coping strategies, which has significant relationship with some socio-demographic and economic correlates such as age, ownership of land, income and ownership of television or mobile phone (as shown in Table 3). The results suggest that older respondents tend to undertake emotion-focused coping strategies and so do the married farmers who show greater propensity to adopt emotionfocused coping strategies (e.g., seeking social support from friends and neighbors) during the period of natural disasters. This is not compatible with the finding of the study carried out by Anyoha et al. [19]. Ownership of land is another determinant of emotion-focused coping strategies. It suggests that farmers having more amount of land show greater tendency to seek social support compared to others. By contrast, participants having more income are less likely to undertake emotion-focused coping strategies such as social support seeking when they are in danger during the time of climatic hazards. Similarly, ownership of television or mobile phone is inversely related to emotion-focused coping strategies, that is, farmers who do not have ownership of television or mobile phone are more likely to report that they seek social support when they are in danger during the period of climatic hazards.

\section{Conclusions}

Bangladesh is the country most susceptible to global climate change in the world. Adaptation has the potential to serve as the best way to mitigate climate change related risk and vulnerabilities [40] [42] [43]. This study was undertaken to examine the influence of farmers' socio-demographic and economic correlates upon their adoption of agricultural, economic and emotion-focused coping and adaptation strategies of climate change in Bangladesh. The results of the study demonstrated that the most common agricultural, economic and emotion-focused coping and adaptation strategies of climate change were social support seeking (79.69\%), planting trees (71.35\%), homestead gardening (52.08\%), hydroponic farming/floating garden (46.88\%), duck rearing (30.73\%), saving (20.83\%), self-insurance (18.75\%), etc. These quantitative findings are further supported by the qualitative findings of the study. The bivariate results indicate that farmers having older age, more income and those who have television or mobile phone are more likely to undertake economic, agricultural and emotion-focused adaptation strategies, whereas respondents having less amount of land and no access to microcredit are less likely to adopt economic adaptation strategies as noted earlier. Again, ownership of land and access to microcredit have correlation with economic and agricultural adaptation strategies. It implies that respondents having less amount of land and no access to microcredit are less likely to adopt economic adaptation strategies, whereas farmers having less amount of land and access to microcredit are more likely to undertake agricultural adaptation strategies. Education, however, is found significantly related to only agricultural adaptation strategies. Data demonstrate that farmers having formal education show greater tendency to adopt agricultural adaptation strategies. With respect to emotion-focused coping strategies, this study finds that married farmers, irrespective of gender, show greater propensity to adopt emotion-focused coping strategies.

Farmers in Barisal district lack financial support from the GOs and NGOs for coping with the climate change related risks and vulnerabilities. In addition, poverty and inadequate knowledge on climate change coping and adaptation strategies are the major contributing factors for dealing with the climate change risks and impacts 
they experience [1]. Finally, this study suggests that continuous researches by policy makers, researchers, GOs and NGOs are very essential to exploring and enhancing their coping and adaptation strategies which may relegate the adverse impacts and vulnerabilities of climate change in the study areas [15].

\section{Acknowledgements}

This study was supported and financed by the University of Dhaka, Bangladesh. This paper was presented in an international conference organized by Bangladesh Sociological Association in conjunction with International Sociological Association on the 22nd of December 2012 at the University of Dhaka, Bangladesh.

\section{Conflict of Interests}

The authors declare that they have no conflict of interests.

\section{References}

[1] Huda, M.N. (2013) Understanding Indigenous People’s Perception on Climate Change and Climatic Hazards: A Case Study of Chakma Indigenous Communities in Rangamati Sadar Upazila of Rangamati District, Bangladesh. Natural Hazards, 65, 2147-2159. http://dx.doi.org/10.1007/s11069-012-0467-z

[2] Ziervogel, G. and Zermoglio, F. (2009) Climate Change Scenarios and the Development of Adaptation Strategies in Africa: Challenges and Opportunities. Climate Research, 40, 133-146. http://dx.doi.org/10.3354/cr00804

[3] Government of Bangladesh (2008) Cyclone Sidr in Bangladesh: Damage, Loss and Needs Assessment for Disaster Recovery and Reconstruction. Government of Bangladesh, Dhaka.

[4] Parveen, S. and Faisal, I.M. (2009) Adaptation to Climate Change: A Case Study on Bangladesh. Earth and Environmental Science, 6, 1-3.

[5] Government of Bangladesh (2007) Climate Change and Bangladesh. Government of Bangladesh, Dhaka.

[6] Seal, L. and Baten, M.A. (2011) Reckoning Climate Change: Local Peoples’ Perception on the Impacts of Climate Change in South-Central and Northern Bangladesh. Unnayan Onneshan Report, Dhaka.

[7] Shahid, S. (2010) Trends in Extreme Rainfall Events of Bangladesh. Theoretical and Applied Climatology, 104, 489499. http://dx.doi.org/10.1007/s00704-010-0363-y

[8] Ministry of Environment and Forest (2009) Climate Change, Gender and Vulnerable Groups in Bangladesh. Department of Environment, Climate Change Cell, Dhaka.

[9] Huda, M.N. (2009) Understanding Farmers’ Perception and Adaptation to Natural Disasters: A Sociological Study in a Village of Barisal District. Unpublished Honors Monograph, University of Dhaka, Dhaka.

[10] Ali, A. (1999) Climate Change Impacts and Adaptation Assessment in Bangladesh. Climate Research, 12, $109-116$. http://dx.doi.org/10.3354/cr012109

[11] Rahman, A.A., Alam, M., Alam, S.S., Uzzaman, M.R., Rashid, M. and Rabbani, G. (2007) Risks, Vulnerability and Adaptation in Bangladesh. UNDP Human Development Report, BCAS, Dhaka.

[12] Adger, W.N., Huq, S., Brown, K., Conway, D. and Hulme, M. (2003) Adaptation to Climate Change in the Developing World. Progress in Development Studies, 3, 179-195. http://dx.doi.org/10.1191/1464993403ps060oa

[13] Tom, M. and Thomas, T. (2006) Adapting to Climate Change Challenges and Opportunities for the Development Community. Institute of Development Studies, Brighton, UK.

[14] Davies, S. (1993) Are Coping Strategies a Cop Out? IDS Bulletin, 24, 60-72. http://dx.doi.org/10.1111/j.1759-5436.1993.mp24004007.x

[15] Anik, S.I. and Khan, M.A.S.A. (2012) Climate Change Adaptation through Local Knowledge in the North Eastern Region of Bangladesh. Mitigation and Adaptation Strategies for Global Change, 17, 879-896. http://dx.doi.org/10.1007/s11027-011-9350-6

[16] Selvaraju, R., Subbiah, A.R., Baas, S. and Juergens, I. (2006) Livelihood Adaptation to Climate Variability and Change in Drought-Prone Areas of Bangladesh: Developing Institutions and Options. FAO, Rome

[17] Enujeke, E.C. and Ofuoku, A.U. (2012) Determinants of Adaptation to Climate Change among Arable Crop Farmers in Edo State, Nigeria and Its Implications for Extension Service. International Journal of Advanced Biological Research, 2, 220-227

[18] Deressa, T.T., Hassan, R.M., Ringler, R., Alemu, T. and Yusuf, M. (2009) Determinants of Farmers' Choice of Adaptation Methods to Climate Change in the Nile Basin of Ethiopia. Global Environmental Change, 19, 248-255. http://dx.doi.org/10.1016/j.gloenvcha.2009.01.002 
[19] Anyoha, N.O., Nnadi, F.N., Chikaire, J., Echetama, J.A., Utazi, C.O. and Ihenacho, R.A. (2013)Socio-Economic Factors Influencing Climate Change Adaptation among Crop Farmers in Umuahia South Area of Abia State, Nigeria. Net Journal of Agricultural Science, 1, 42-47.

[20] Nwaiwu, I.U.O., Ohajianya, D.O., Orebiyi, J.S., Eze, C.C. and Ibekwe, U.C. (2013) Determinants of Agricultural Sustainability in Southeast Nigeria-The Climate Change Debacle. Global Journal of Agricultural Research, 1, 1-13.

[21] Franzel, S. (1999) Socio-Economic Factors Affecting the Adoption Potential of Improved Tree Fallows in Africa. Agroforestry Systems, 47, 305-321. http://dx.doi.org/10.1023/A:1006292119954

[22] Shiferaw, B. and Holden, S. (1998) Resource Degradation and Adoption of Land Conservation Technologies in the Ethiopian Highlands: A Case Study in AnditTid, North Shewa. Agricultural Economics, 18, 233-247. http://dx.doi.org/10.1016/S0169-5150(98)00036-X

[23] Hobfoll, S.E. (1988) Stress, Culture, and Community: The Psychology and Philosophy of Stress. Plenum, New York.

[24] Hobfoll, S.E. (2001) The Influence of Culture, Community and the Nested-Self in the Stress Process: Advancing Conservation of Resources Theory. Applied Psychology, 50, 337-396. http://dx.doi.org/10.1111/1464-0597.00062

[25] Zamani, G.H., Gorgievski-Duijvesteijn, M.J. and Zarafshani, K. (2006) Coping with Drought: Towards A Multi-Level Understanding Based on Conservation of Resources Theory. Human Ecology, 34, 677-692. http://dx.doi.org/10.1007/s10745-006-9034-0

[26] Hobfoll, S.E. and Lilly, R.S. (1993) Resource Conservation as a Strategy for Community Psychology. Journal of Community Psychology, 21, 128-148. http://dx.doi.org/10.1002/1520-6629(199304)21:2<128::AID-JCOP2290210206>3.0.CO;2-5

[27] Hobfoll, S.E. (1998) The Ecology of Stress. Hemisphere, New York.

[28] Coelho, A.E.L. (2000) Psychological Responses to Drought in North-eastern Brazil: An Exploratory Study. Unpublished Ph.D. Thesis, University of Manitoba, Manitoba.

[29] Fetsch, R.J. (2003) Managing Stress during Tough Times. Colorado State University Cooperative Extension. Fact Sheet No. 10.255.

[30] Bangladesh Bureau of Statistics (2012) Population and Housing Census 2011: National Report. Bangladesh Bureau of Statistics, Dhaka.

[31] Banglapedia (2012) National encyclopedia of Bangladesh. Asiatic Society of Bangladesh, Dhaka.

[32] Uddin, J. (2010) Dynamics of Cyclone Evacuation Behavior among Southwestern Coastal Residents in Bangladesh: A Case Study of Cyclone Sidr. Journal of Emergency Management, 8, 63-71. http://dx.doi.org/10.5055/jem.2010.0027

[33] Hannigan, J.A. (1995) Environmental Sociology: A Social Constructionist Perspective. Routledge Press, London.

[34] Ayanwuyi, Kuponiyi, E., Ogunlade, F.A. and Oyetoro, J.O. (2010) Farmers’ Perception of Impact of Climate Changes on Food Crop Production in Ogbomosho Agricultural Zone of Oyo State, Nigeria. Global Journal of Human Social Science, 10, 33-40.

[35] Ishaya, S. and Abaje, I.B. (2008) Indigenous People’s Perception on Climate Change and Adaptation Strategies in Jema’a Local Government Area of Kaduna State, Nigeria. Journal of Geography and Regional Planning, 1, 138-143.

[36] Huber, T. and Pedersen, P. (1997) Meteorological Knowledge and Environmental Ideas in Traditional and Modern Societies: The Case of Tibet. Journal of the Royal Anthropological Institute, 3, 577-598. http://dx.doi.org/10.2307/3034768

[37] Narain, V. (2003) Institutions, Technology and Water Control: Water Users Associations and Irrigation Management Reform in Two Large-Scale Systems in India. Orient Longman, Hyderabad.

[38] Rahman, A.A., Alam, M., Alam, S.S., Uzzaman, M.R., Rashid, M. and Rabbani, G. (2007) Risks, Vulnerability and Adaptation in Bangladesh. UNDP Human Development Report, Dhaka.

[39] Ahmed, A.K. and Chowdhury, E.H. (2006) Study on Livelihood Systems Assessment, Vulnerable Groups Profiling and Livelihood Adaptation to Climate Hazard and Long Term Climate Change in Drought Prone Areas of NW Bangladesh. Final Report for the Food and Agriculture Organization (FAO) and Department of Agricultural Extension, Dhaka.

[40] Hossain, M.S. and Roy, K. (2010) Community Based Risk Assessment and Adaptation to Climate Change in the Coastal Wetlands of Bangladesh: A Case Study from Chenchuri Beel, Narail, Bangladesh. Proceedings of International Conference on Environmental Aspects of Bangladesh (ICEAB10), Japan, 5 September 2010, 29-32.

[41] Daulagala, C., Weerahewa, J., Marambe, B., Pushpakumara, G., Silva, P., Punyawardena, R., Premalal, S., Miah, G., Roy, J. and Jana, S. (2013) Socio-Economic Characteristics of Farmers Influencing Adaptation to Climate Change: Empirical Results from Selected Home Gardens in South Asia with Emphasis on Commercial Orientation. Sri Lanka 
Journal of Advanced Social Studies, 2, 71-90.

[42] World Bank (2000) Bangladesh: Climate Change and Sustainable Development. World Bank Report No. 21104 BD.

[43] Maharjan, S.K., Sigdel, E.R., Sthapit, B.R. and Regmi, B.R. (2011) Tharu Community's Perception on Climate Changes and Their Adaptive Initiations to Withstand Its Impacts in Western Terai of Nepal. International NGO Journal, 6, 35-42. 